Dana Tometzová ${ }^{1}$, Barbara Hlavňová2, Slavomír Drevko³, Katarína Pukanská ${ }^{4}$ Karol Bartoš ${ }^{5}$, Agnieszka Bieda ${ }^{6}$, L’ubomír Kseňak ${ }^{7}$

\title{
The Development of Geotourism with the Use of 3D Digital Cave Model. A Case Study of the Bear Cave, Slovakia ${ }^{8}$
}

\begin{abstract}
Cave tourism (speleotourism) is very popular all over the world within the broader category of geotourism. Slovakia is also well-known for its karst areas and caves, but most of them are not freely open to the public. This paper presents how to make a cave "accessible" without physically entering it. This can be facilitated through the use of digital 3D models. Visitors are then able to experience cave tours through 3D projections and 3D cinema. This would allow people with disabilities and those with claustrophobia to enjoy caving. An added advantage is that the cave environment remains untouched. This paper provides a comprehensive scan of the Bear Cave using Leica ScanStation C10 terrestrial laser scanner. During the 3D modelling of the Bear Cave, Trimble RealWorks software was used to process and analyze the large data sets recorded by the scanner. As a result, not only were visualizations and images of 3D models from the cave obtained, but also a 3D animation was made using the Bentley Pointools software. The information included in this paper has been compiled from all phases of the measuring and data processing of the Bear Cave.
\end{abstract}

Keywords: geotourism, digital 3D model, terrestrial laser scanning, Slovak Paradise, Bear Cave

Received: 7 October 2019; accepted: 5 December 2019

(C) 2020 Authors. This is an open access publication, which can be used, distributed and reproduced in any medium according to the Creative Commons CC-BY 4.0 License.

1 Technical University of Košice, Slovakia, email: dana.tometzova@tuke.sk ORCID ID: https://orcid.org/0000-0001-7857-0263

2 Technical University of Košice, Slovakia, email: barbara.hlavnova@tuke.sk

3 Technical University of Košice, Slovakia, email: slavomir.drevko@tuke.sk

4 Technical University of Košice, Slovakia; Kielce University of Technology, Poland, email: katarina. pukanska@tuke.sk

ORCID ID: https://orcid.org/0000-0002-7332-7691

5 Technical University of Košice, Slovakia, email: karol.bartos@tuke.sk ORCID ID: https://orcid.org/0000-0002-4870-5494

6 AGH University of Science and Technology, email: agnieszka.bieda@agh.edu.pl ORCID ID: https://orcid.org/0000-0002-9725-5960

7 Technical University of Košice, Slovakia, email: lubomir.ksenak@tuke.sk

8 The study is the result of the Grant Project of the Ministry of Education of the Slovak Republic VEGA No. 1/0844/18: "Experimental research on the limiting factors of application of non-contact surveying systems for the documentation of specific surfaces for the creation of their digital models" 


\section{Introduction}

Geotourism is a form of tourism that sustains or enhances the geographical character of a place - its environment, culture, aesthetics, heritage, and the well-being of its residents. The latest definition of a geotourism is presented by Hose [1]: "Geotourism is the provision of interpretative and service facilities for geosites and geomorphosites and their encompassing topography, together with their associated in-situ and ex-situ artefacts, to constituency-build for their conservation by generating appreciation, learning and research by and for current and future generations".

According to Wimbledon [2], a geosite can be defined as a site location, area or territory in which it is possible to identify a geological or geomorphological interest for conservation. On the basis of this definition, we can definitely denominate caves as geosites and cave tourism (speleotourism) as a part of geotourism.

However, the development of cave tourism is also linked to the increase in the number of visitors in caves and the subsequent destruction of the cave environment. Dernas, Maekawa, Bell \& Agnew [3] focused in their work on sustainable visitation and factors which can highly influence the sustainability of a cave environment like acceptable carbon dioxide levels, elevated humidity, temperature changes, air exchange rate, effects of visitors on the microenvironment etc. The visitor carrying capacity of caves in connection with the conservation of the speleological heritage was also considered by Jurinčič \& Balažič [4]; Lobo \& Moretti [5]; and Lobo et al. [6]. Some works were more aimed at the conservation of cave bats - Furey \& Racey [7]; or Cardiff, Ratrimomanarivo, Rembert \& Goodman [8]. Cave visitors exert a considerable influence on cave spaces (as we mentioned above: fluctuations in temperature, humidity and carbon dioxide concentrations) but also the process of the opening of a cave is dangerous for cave fauna and the whole ecosystem. It involves the introduction of artificial lighting, physical modifications in the form of entrance structures, walkways, stairs or other artificial equipment.

The focus of the paper is to promote a cave in the area of Slovak Paradise National Park through 3D modelling. Considering the fact that it is a highly protected area, the best way to make this cave accessible for the public is to create a 3D model in a digital form. Numerous authors have devoted their attention to the development of cave tourism (speleotourism) by virtual means. Cosso, Ferrando \& Orlando [9] made a 3D reconstruction of the Pollera cave in Italy. Buchroithner \& Gaisecker [10] digitally reproduced the cave in Dachstein Region. Custódio, Dantas, Prata, Donato \& Morato [11] created a didactic-inclusive tool for speleotourism accessibility, especially for people with reduced mobility. Others who have devoted their attention to the modelling of caves were Cui, Chow \& Zhang [12]; Ballesteros, Jiménez-Sánchez \& Domínguez-Cuesta [13]; Remondino [14]; Leonov et al. [15]; Núňez et al. [16]; or Gallay et al. [17]. 
With advancements in computer technology, including processing various graphics operations, the potential to use geographical information systems have increased [18]. Modelling of cave geosystems and other geological objects may be carried out through various programs and applications.

According to Chen [19], 3D modelling is the process of developing the mathematical expression of the three-dimensional surfaces of the object by using specialized software, and the result is called a 3D model. It can be displayed through a process called 3D rendering. 3D modelling is a supposition for its further multilateral use.

3D models can be created physically, through algorithms (process modelling) or by "scanning" with the support of technical tools. In general, modelling consists of creating individual objects that are later used in the environment. There are many modelling techniques including constructive geometry, implicit surfaces or surfaces division.

The above-mentioned authors and their publications have analyzed the 3D modelling process in detail, or were focused on the sustainability of cave systems through visitor carrying capacity, but they did not dedicate their attention (or only marginally) to the connection of 3D models with the development of geotourism in selected (geo)tourist sites. The aim of this paper, through our theme park proposal (see Chap. 5.1), is to highlight the potential and practical uses of 3D models or visualizations that can change an uninteresting tourist site into a popular (geo)tourist attraction and thus contribute to the development of geotourism in the selected area.

\section{3D Modelling and Its Current Use in Geotourism}

Currently, there are countless numbers of software programs for creating 3D models. Generally, the programs are divided into graphics and technical modelling. The most common graphical modelling programs include 3Ds Max, Maya, Rhino, Lightwave, Cinema 4D, XSI, Blender, ZBrush and the most frequently used programs for technical modelling are: CATIA, PRO/ENGINEER, Solid-Edge, I-DEAS, SolidWorks, AutoCAD, Inventor.

In Hungary, the technology has already been utilized for a unique paleontological exhibition in Ipolytarnóc - Geopark Novohrad (Fig. 1). Prehistoric development is shown by means of $3 \mathrm{D}$ projection and $4 \mathrm{D}$ cinema. Such a form of presentation can be used in areas which are not accessible to tourists. The 3D projection room, as well as the $4 \mathrm{D}$ cinema, are part of the nature conservation efforts in Ipolytarnóc. Visitors can travel in time and see osteological remains of animals as well. This $4 \mathrm{D}$ movie is not just educational, but it is also a form of adventure because the cinema is equipped with moving seats and various simulations. The seats are equipped with safety belts and the visitor experience is designed to be as real as possible. 
a)

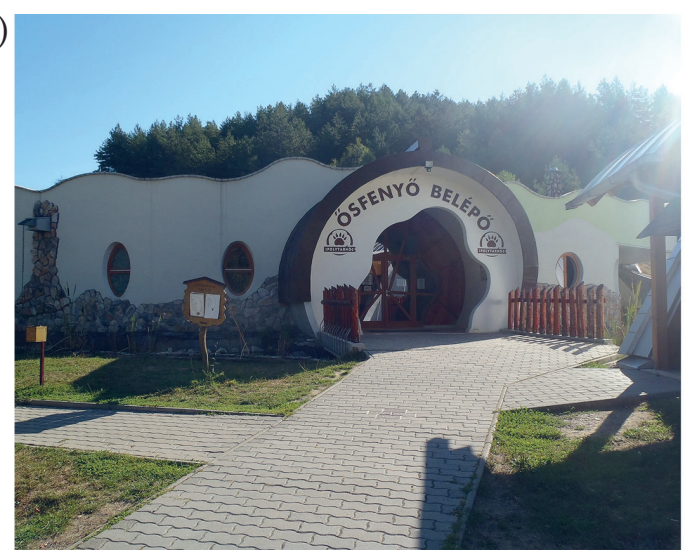

b)

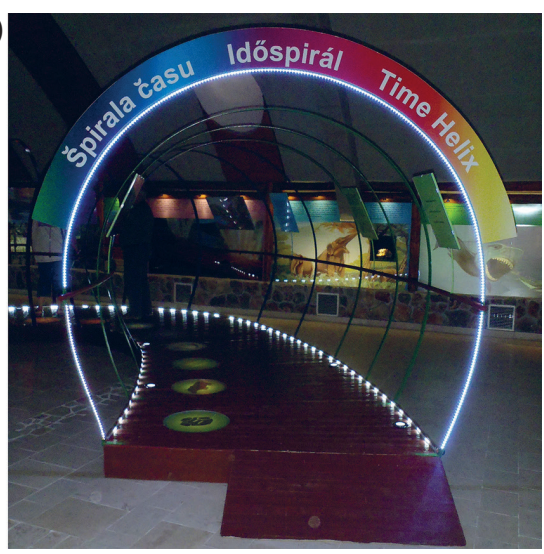

Fig. 1. Ipolytarnóc, Hungary:

a) the entrance building with 4D cinema; b) Time Helix Exhibition

The Queensland Museum in Brisbane, Australia used 3D modelling and multimedia interactive displays to bring the prehistoric past alive [20]. The general public can see real fossils, but also three-dimensional reconstructions of prehistoric animals - more than 100 life-sized projections of dinosaurs, as well as ancient marine reptiles or tiny fossils.

Other paleontological - themed offerings are available at the National Geographic Museum in Washington D.C., United States. Visitors can take a trip back in time to 95 million years ago. The exhibition includes 3D movies about dinosaurs or $3 \mathrm{D}$ virtual exhibits to different caves.

Visitors to the currently disused colliery in Hemingfield, in the north of England, can experience the exhibition with the use of 3D modelling and virtual reality as well. Wearing a VR headset, the user is taken down into a stunning recreation of the coal mine as it would have been in the early 1900s.

3D modelling was also used in famous Paleolithic site - the Denisova Cave in the Altai Mountains, Russia. The 3D model was created by Leonov et al. [15] as part of a project called Virtual Modelling and 3D Documentation in the History of Science and Technology. Except for the detailed 3D model of a cave, they scanned, imaged and modelled several finds of stone implements in the cave. The 3D model and software created can be used for presentations as well as research tasks (for example, visual analysis of stratigraphy and deposition of sediments). The presentation can also be used for virtual travel in the cave, including free online tours. It is especially important for such remote and hard to access heritage sites as the Denisova Cave in the Altai Mountains.

Another example is the Sculptor's Cave in Moray, Scotland, which is also inaccessible to the broader public. The digital model created by Bradford's School of Archaeological and Forensic Sciences will be deposited in the Elgin Museum and included in their exhibition on the cave. 
Since the presence of humans threatened to cause damage to the famous paintings in Lascaux Cave, France, the cave was closed to the public in 1963. Artists used 3D digital scanning to make an exact replica of the original cave, and now visitors can see interactive exhibits in the adjoining museum. The realization of the 3D modelling project was described by Feruglio, Péral \& Aujoulat [21].

Carmo \& Cláudio [22] devoted their attention to 3D virtual exhibitions and museums by the use of different tools. A wide range of applications are presented in their study to exemplify the different requirements and techniques used in generating a virtual environment.

Currently, several technologies can be successfully used to map underground spaces. The most suitable technologies for the creation of 3D models of caves are terrestrial laser scanning (TLS) and digital photogrammetry. Photogrammetry is a science that deals with the reconstruction of the shape, size, and position of objects (or surfaces), using images to do so [23]. It is a non-contact measuring technology, which can provide results like numerical data (coordinates, surfaces, volumes, etc.), as well as graphical data (maps, orthophotos, CAD data, etc.). However, one of the necessary prerequisites for achieving quality results from photogrammetric processing is sufficient illumination of the measured surfaces, which can often be a challenging task in the case of underground spaces. Terrestrial laser scanning uses a laser beam with the polar method of measurement, where the vertical angle, horizontal angle and slope distance are measured for individual scanned points. During the scanning process, the laser beam is deflected at high speed using a rotating mirror, which allows a large number of points to be measured in a short time. A point cloud is the result of laser scanning, i.e. a set of points with known spatial coordinates in the respective coordinate system, while each point can also have the value of the intensity of the reflected signal defined, and RGB information (if a digital camera is used to record also textural information). The possibility of using laser scanning, even in full darkness, is a great advantage of this technology. On the other hand, the laser beam cannot "bend" and therefore measuring all the details (especially in caves with complex decoration) can often be very difficult. It follows that in the case of this work, the technology of TLS was used, especially due to the absence of any illumination in the whole cave $[24,25]$.

\section{Study Area}

According to the Slovak Cave Administration [26], there are approximately 7,100 known caves in Slovakia, the majority of which are not open to the public. Accessibility is limited to just 16 of them due to ongoing research, unsafe conditions, difficulties in navigating the underground environment, and lack of financial resources to install electrical and lighting facilities. Once a cave is entered, deterioration begins and it is therefore imperative that conservation, maintenance and protection of the fragile 
environment should begin as soon as possible. This course of action is necessary for future generations to have the same access to these natural environments.

All proposals relating to tourist activity inside the cave's geosystems, or near to it, have to be carried in accordance with karst ecology (eco-karstology). It is, therefore, necessary to evaluate geological bearing capacity, the stability of cave systems, make an assessment of Karst carrying capacity and the impact of anthropogenic activity on karst terrain. Consideration should be given to the security conditions of caves as well - monitoring concentrations of $\mathrm{CO}_{2}$ is necessary to ensure adequate ventilation or restrict the movement of persons in the cave. Attention should be paid to short-term fluctuations, seasonal eco-cycles and long-term geosystem changes.

The Slovak Paradise National Park (Eastern Slovakia) is one of the youngest national parks in Slovakia. It contains about 350 caves, but only Dobšinská Ice Cave is freely open to the public. One of the non-accessible caves is the Bear Cave (Fig. 2), which is located on the edge of the Glac plateau [27]. It is one of the biggest and most important paleontological sites in the Slovak Republic (Fig. 2). This cave is characterized by a profusion of Ursus spelaeus bones, a wide representation of various species of hibernating bats, the presence of Paleogene rocks, the occurrence of minerals such as phosphorus, diverse range cave fillings and beautiful stalagmites, stalactites and other cave formations [28, 29]. As a result, the cave is listed as a National Natural Monument of Slovakia and the cave is not open to the public. However, scientific and speleological research, as well as the evaluation of the economic and educational potential of the cave, is ongoing.

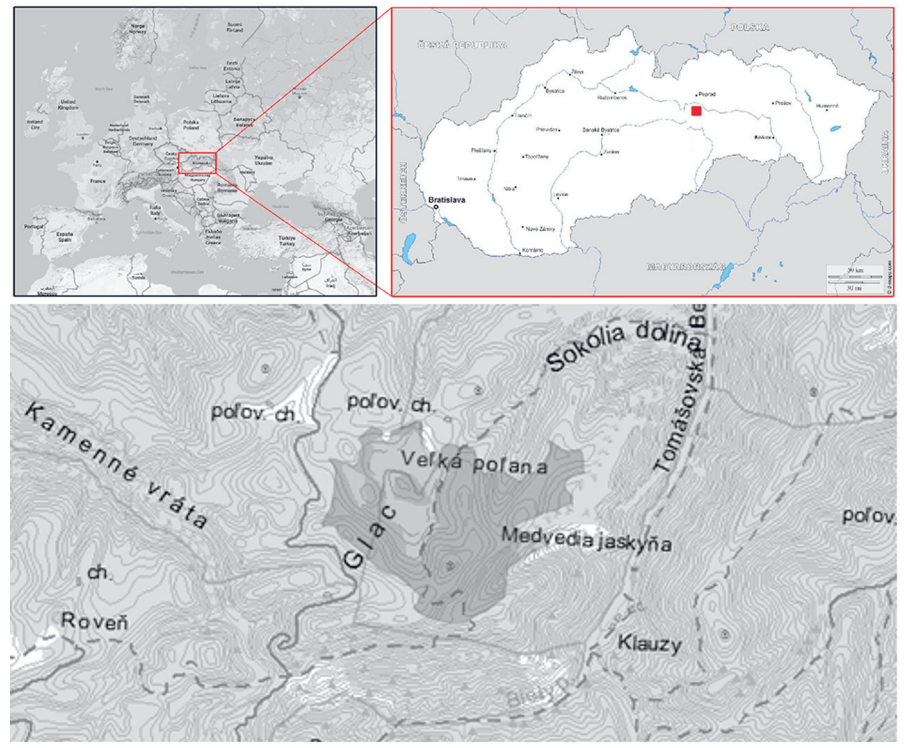

Fig. 2. Location of the Bear Cave Source: [30] 


\subsection{History and Description of the Bear Cave}

The Bear Cave (Fig. 3), formed by an underground stream, was discovered on October 27, 1952, by members of Slovak Speleological Society from Spišská Nová Ves - V. Pleva, J. Dinka, P. Halaš and L. Kvietok [31, 32]. The length of the mapped areas is $497 \mathrm{~m}$, and the elevation is $30 \mathrm{~m}$. The lowest point in the cave is located at the entrance, and the highest point (933 m a.s.l.) is in the northern part of the Dionýz Štúr Hall. Groundwater flows here from the Vel'ká Pol’ana platform. In 1972, the Bear cave was listed as a National Nature Monument of Slovakia.

The cave consists of the following parts (Fig. 4) [31, 32]:

- Entrance Corridor,

- Crossroads,

- Gorges,

- Dome of Dionýz Štúr,

- Hall of Discoverers,

- Pillar Hall,

- Pond Corridor,

- Labyrinth,

- Cave Bear Cemetery,

- Ossuary,

- Hall of Slovak Speleologists.

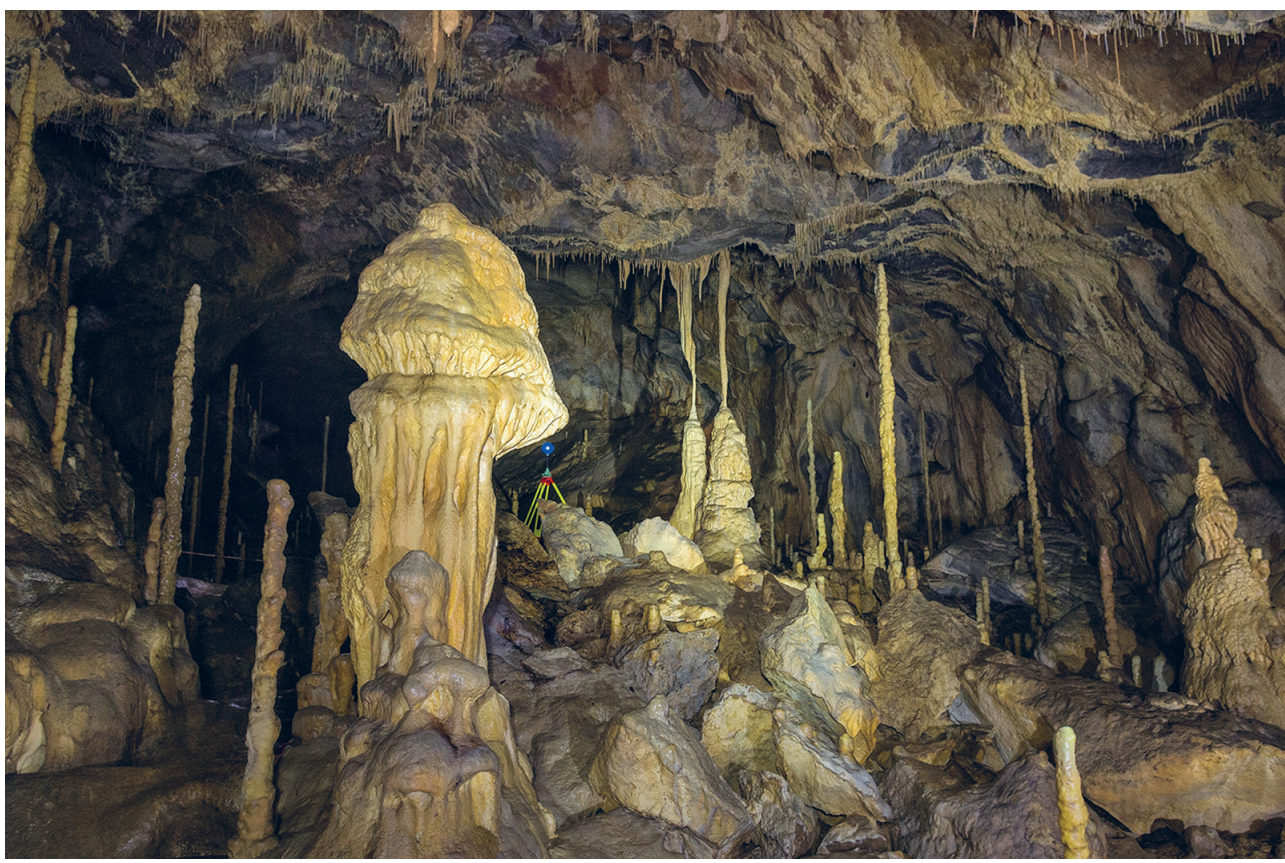

Fig. 3. Bear Cave, Slovak Paradise 


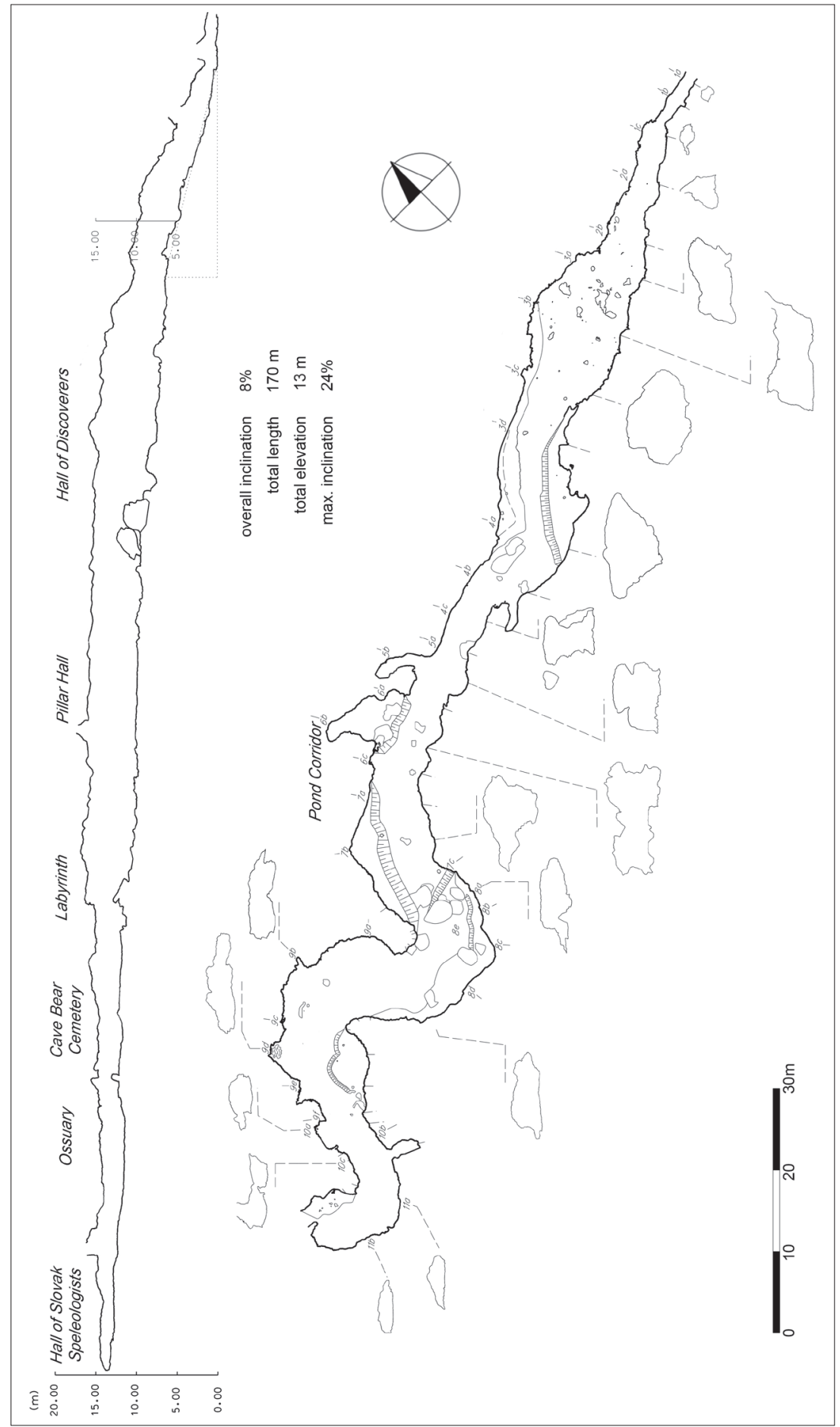


The most striking feature of the cave is $40 \mathrm{~m}$ long and the $20 \mathrm{~m}$ wide Pillar Hall. It boasts a unique drip stone ornamentation which is yellowish in colour, sinter lakes, palm trees and stalactite decorations. Stalagmites reaching up to $3 \mathrm{~m}$ can be found here, as well as soda straws of different lengths.

The color spectrum of the cave fillings is very diverse, ranging from white through yellowish and light brown, which is dominant for the youngest formations. Older units have a reddish colour. Equally varied is the composition of cave sediments. Prominent features in some parts of the cave are sinter fragments of fine-grained ochre sandstone with isolated parts of limonite nodules. Below them is a layer formed by brown-reddish, compacted sedimentation of clay with a slight edge lamination. They are greatly enhanced fluvial sediments as well, which consisting of gravel, clay and sand. Represented are also Paleogene sandstone balls, but the majority consists of rounded fragments of residual iron ores, such as limonite and goethite. These sediments are allochthonous in origin [33].

Attention should be paid to the common appearance of "bear mirrors" - polished surfaces on limestone boulders and walls which are located mainly in Pillar Hall, Cave Bear Cemetery, and Pond Corridor. Their formation is associated with the fact that bears nuzzled up against these limestone walls and surfaces in an attempt to get rid of skin parasites.

The towering pagoda stalagmites are usually $2-3 \mathrm{~m}$ high, and sinter crusts are 5-20 cm thick. The exceptions are sinter plates behind "Ossuary" which are up to $1 \mathrm{~m}$ thick. Their estimated age is over 350,000 years. Stalactites can be found in short soda straw forms ("Hall of Slovak Speleologists", "Cave Bear Cemetery", "Ossuary") or a hanging form with lengths of up to $1 \mathrm{~m}$.

The bottom of the cave passages is covered with fluvial sediments with numerous paleontological findings related to cave bears (bear bones, droppings, etc.). There is an entire cemetery of cave bears. There have been findings of bones belonging to younger but also older cave bears, dating back over 15,000 years. There are now nine hibernating species of bats, of which the most numerous is Myotis Myotis and Rhinolophus Hipposideros, residing in the Bear Cave.

Once the final examination of the Bear Cave is complete, it may become one of the most visited sites in the Slovak Paradise. To date, $497 \mathrm{~m}$ has been explored and documented; at certain points, there is a vertical range of $30 \mathrm{~m}$. A recent survey predicts that there also should be an ice cave, which would be a rare discovery. Thanks to the sustained, relatively low temperature, as well as relatively high humidity, the cave bear bones were well preserved from the last ice age.

\subsection{The Findings of Ursus Spelaeus in the Bear Cave}

Cave bears (UrsusSpelaeus, Fig. 5) were found in all of Europe and some parts of Asia up until their extinction. In comparison to the brown bear, cave bears had bigger and wider skulls with a relatively high and perpendicular forehead. The weight of this bear was estimated to be $600 \mathrm{~kg}$ (according to some researchers even 
up to one tonne) and a height of up to $3.5 \mathrm{~m}$. On average, cave bears were about a third taller than today's brown bears, and the males tended to be larger than females. Cave bears most closely resemble today's North American grizzly bear and lived for an estimated 20 years [34,35]. This giant among bears suffered from significant climate change, which occurred about 28,000 years ago. Cave bears, cave lions and mammoths became extinct during approximately the same time period. Based on the remains of the skull and teeth, scientists can determine specifically the diet of cave bears, which was primarily vegetation.

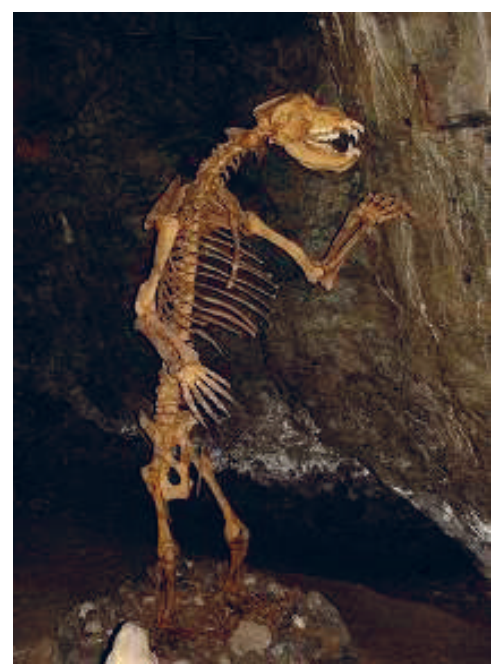

Fig. 5. Skeleton of the cave bear Source: [36]

There were groups of hunters who were specialized in hunting cave bears. Its fur could be exchanged for goods which they did not have access to (claws, mammoth ivory). Several European caves (France, Spain), have been linked to cults centered around cave bears. It is assumed that for these tribes it was also a totem symbol. Thanks to the efforts of some in these communities, drawings of cave bears have been found on the walls of caves and overhangs. Stone shelves were also found in these caves, where the skulls of cave bears were placed, as well as on the central stone in the cave, which was the main place for worship [37].

Many European caves are named after their "inhabitants" - the bears. In China, bear bones were used for traditional medicinal purposes. Significant findings of cave bear bones come mainly from Italy, Switzerland, Romania, Serbia and recently also in Slovakia, where we have 21 caves with the word bear in the title, but the most famous is Bear Cave in the Slovak Paradise. Caves open to the public where the bones of cave bears have been found are Važecká cave, Jasovská cave, Demänovská Cave of Liberty, and Demänovská Ice Cave. 


\section{Methods, Equipment and Application}

The terrestrial laser scanning of the Bear Cave was realized in the following steps:

1. transport of the necessary equipment through the entrance corridor into the cave;

2. terrain reconnaissance in the cave, and planning the placement of individual scanning stations for TLS to capture as much as possible from the cave surface and morphology;

3. the actual laser scanning from individual scanning stations.

The Leica ScanStation C10 terrestrial laser scanner (Fig. 6) was used for the scanning. Since the resulting point clouds from individual scanning stations should be registered together and transformed into a common coordinate system, the scanner has to be spatially oriented at each new scanning station to another already known spatial point. For this purpose, the Leica 6" circular tilt \& turn targets (Fig. 7) were used. Technical specifications of the scanner are given in Figure 6. Since the theoretical maximum speed of scanning is up to 50,000 points/s, we can obtain data in the form of a point cloud with height-density of points in a relatively short time, and, therefore, a high level of detail in the resulting 3D model.

Since the cave is situated in a hardly accessible terrain with a narrow entrance corridor, a geodetic connection (positional and vertical) to the national coordinate system was not feasible. Therefore, all scanning works were realized in a local coordinate system.

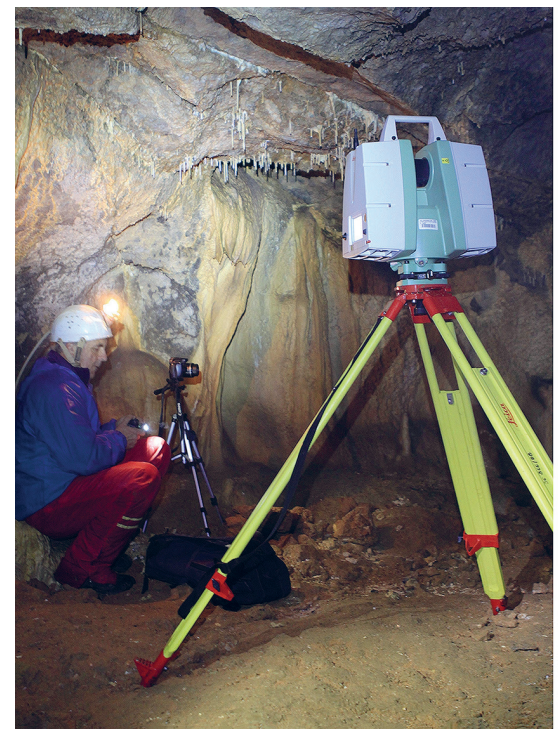

\begin{tabular}{|c|c|}
\hline \multicolumn{2}{|c|}{ Technical specification of the laser scanner } \\
\hline \multicolumn{2}{|c|}{ Accuracy of single measurement } \\
\hline Position/Distance & $6 \mathrm{~mm} / 4 \mathrm{~mm}$ \\
\hline \multicolumn{2}{|c|}{ Angle precision } \\
\hline Horizontal/Vertical & $12^{\prime \prime} / 12^{\prime \prime}$ \\
\hline $\begin{array}{l}\text { Modelled surface } \\
\text { precision }\end{array}$ & $2 \mathrm{~mm}$ \\
\hline Range & $\begin{array}{l}300 \mathrm{~m} \text { (90\% reflectivity) } \\
134 \mathrm{~m}(18 \% \text { reflectivity })\end{array}$ \\
\hline $\begin{array}{l}\text { Minimal step of } \\
\text { scanning }\end{array}$ & $1 \mathrm{~mm}$ \\
\hline Scan rate & $50000 / \mathrm{sec}$ \\
\hline Laser class & $3 \mathrm{R}$, green $(\lambda=532 \mathrm{~nm})$ \\
\hline Spot size & $0-50 \mathrm{~m} \approx 4,5 \mathrm{~mm}$ \\
\hline \multicolumn{2}{|c|}{ Field of view } \\
\hline Vertical/Horizontal & $270^{\circ} / 360^{\circ}$ \\
\hline
\end{tabular}

Fig. 6. Terrestrial laser scanner Leica ScanStation C10 
Spatial objects scanned by a terrestrial laser scanner can be too large and complex to be scanned from one scanning station (especially in the case of caves). Therefore, they must be scanned from multiple stations in order to capture them in their entirety and to generate an accurate model. The resulting product of 3D scanning is a scanned object that is displayed by using the appropriate software in the form of a point cloud (Figs. 8, 9). From the corresponding point cloud, it is subsequently possible to model this object. Due to the complexity of the Bear Cave, it was necessary to use a total of 14 scanning stations. Since the cave is not freely open to the public, there are no walkways, handrails, platforms, or any other equipment. Therefore, all the scanning stations (and movement in the cave in general) had to be chosen and realized very carefully in order to not damage the cave decoration.

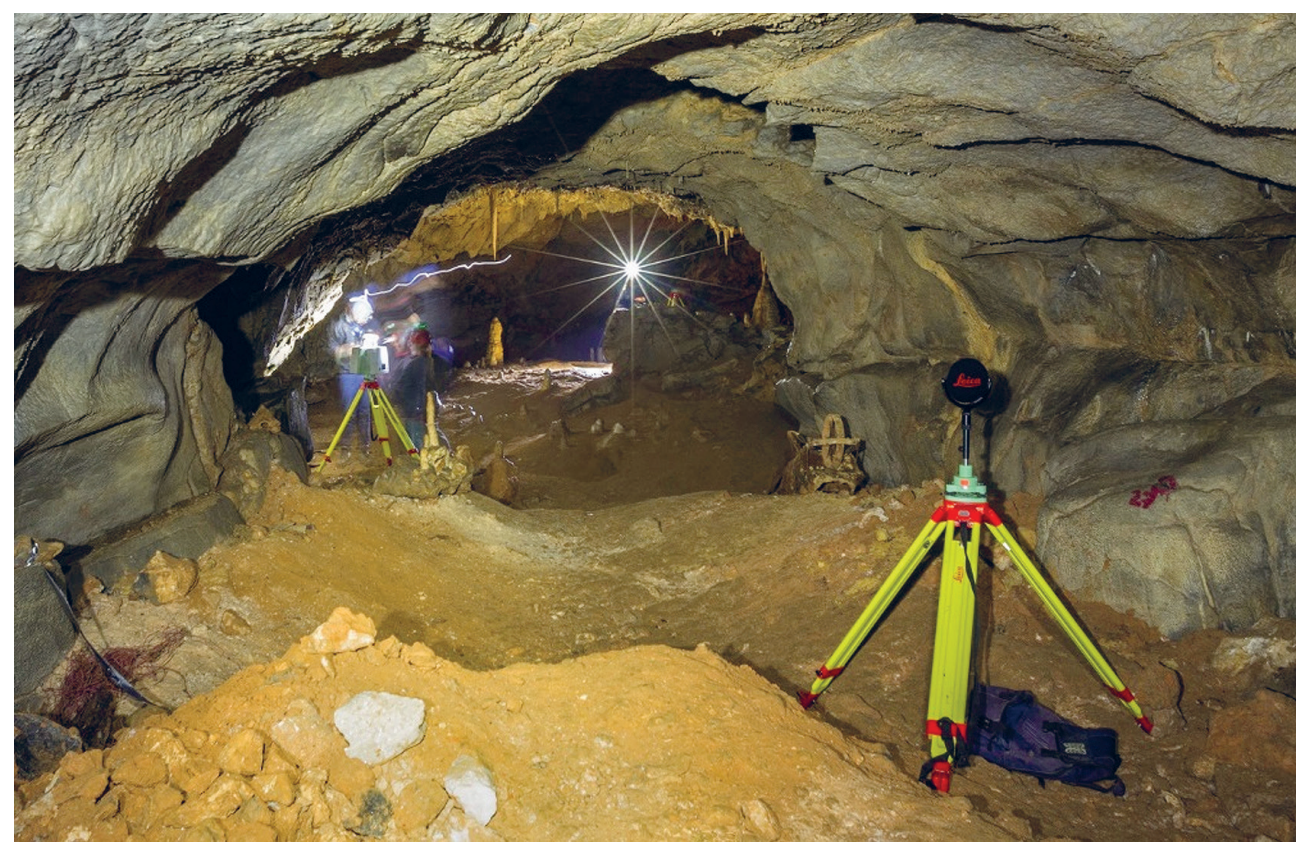

Fig. 7. Laser scanning of the Bear Cave

Subsequent processing of the obtained data was performed in these phases:

1. downloading the final project from the scanner hard drive and importing into the processing software - Leica Cyclone;

2. basic editing - inspecting the resulting point cloud, trimming unwanted parts, deleting noise and outliers, exporting into a suitable exchange format (*.pts); the final point cloud contained approx. 54 mil. points;

3. importing data into the CloudCompare software, suitable also for point cloud processing;

4. generating the $3 \mathrm{D}$ model of the cave; 
5. analyzing the data derived from the model (area, volume, ground plan, cross-sections, etc.);

6. generating video animation and high-resolution images for presentation purposes in Bentley Pointools software (Figs. 8-11).

The following software was used for the whole data processing: Leica Cyclone 7.4.1, CloudCompare 2.6.0, Bentley MicroStation PowerDraft V8i - SS2, and Bentley Pointools V8i.

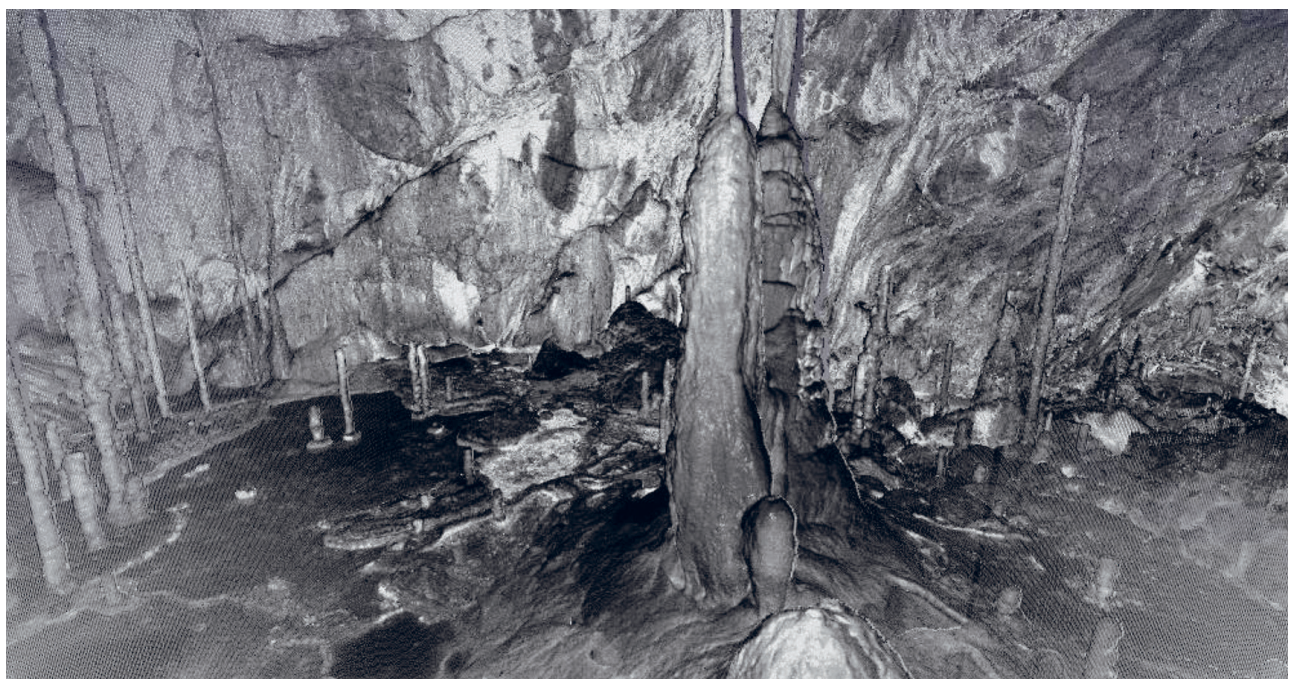

Fig. 8. Point cloud of the Bear Cave in Slovak Paradise - part 1

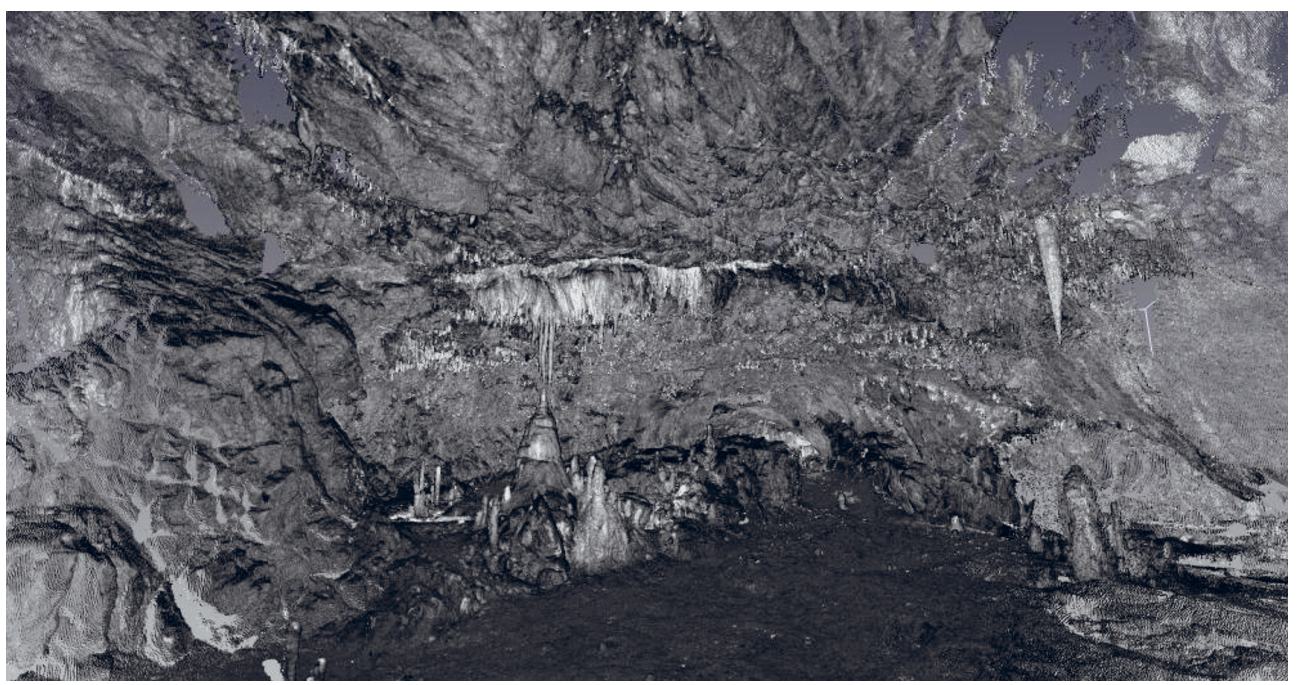

Fig. 9. Point cloud of the Bear Cave in Slovak Paradise - part 2 


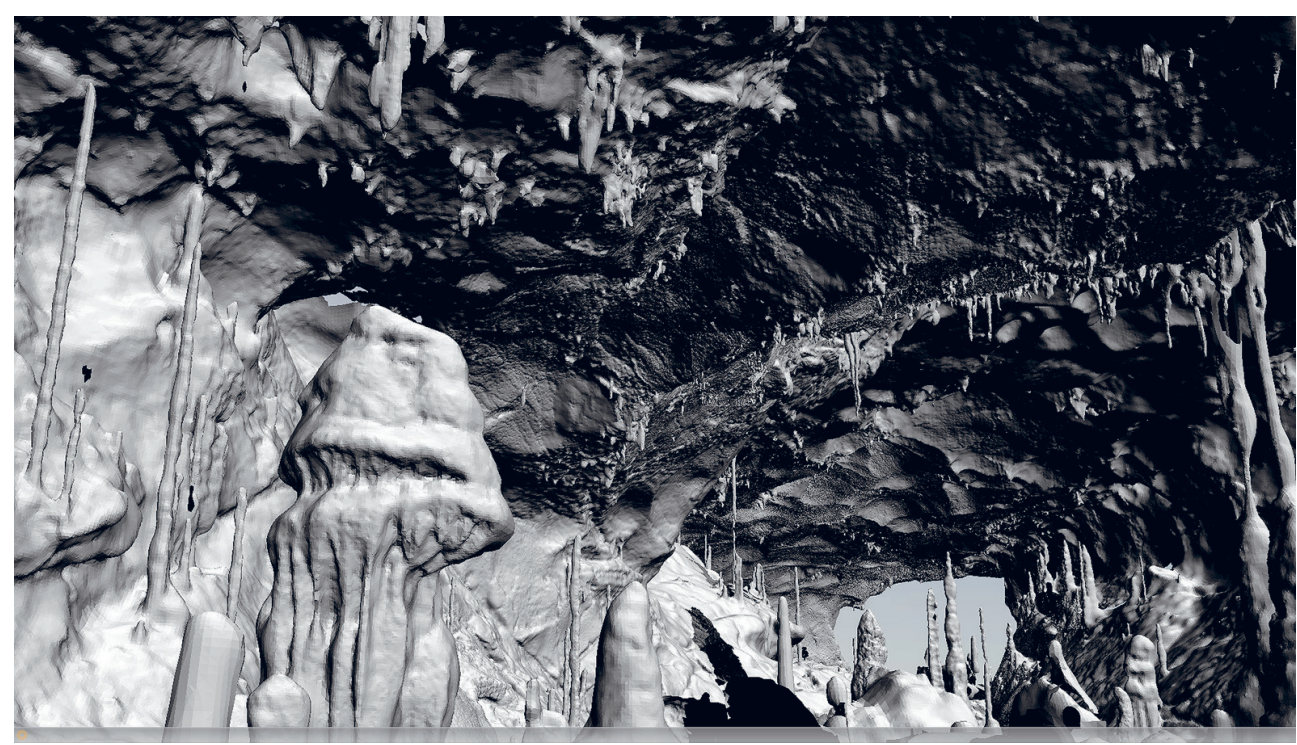

Fig. 10. 3D model of Bear Cave

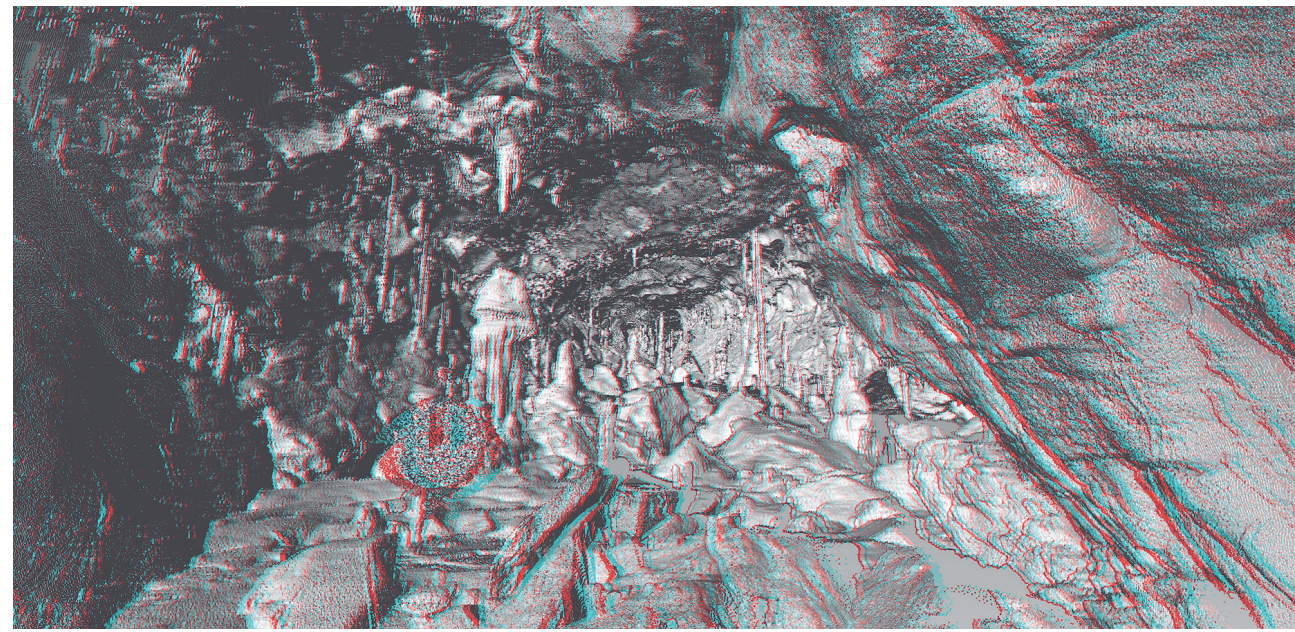

Fig. 11. A high-resolution image of the cave in the 3D display

\section{Results and Discussion}

Different graphics software was used to perform the processing of point clouds, their filtering, modelling, creating and exporting the visualization. After creating the digital outputs in the form of a 3D spatial cave model, they were converted into analogue form as maps, transversal and longitudinal cross-sections, etc., of the mapped cave passages. In the Bentley software, various views of the cave were created and converted into maps. 
Due to the large data volume of the resulting point cloud, the modelling of the Bear Cave was carried out after the division of the point cloud into several smaller sections. 3D modelling was realized in the CloudCompare software, using Poisson Surface Reconstruction [38] with Octree Depth 12 (Fig. 10). Afterwards, their combination resulted in the final 3D model of the cave. An animation was also made (directly from the point cloud), using the original cloud density. Any noise, outliers, and unwanted objects were edited and filtered in the Leica Cyclone software. The animation itself was created and rendered in the Bentley Pointools software. The software is also suitable to create animations or images in the 3D display, which can be very suitable and desirable for presentation purposes (Fig. 11). The general workflow, with all the surveying and processing steps, is shown in Figure 12.

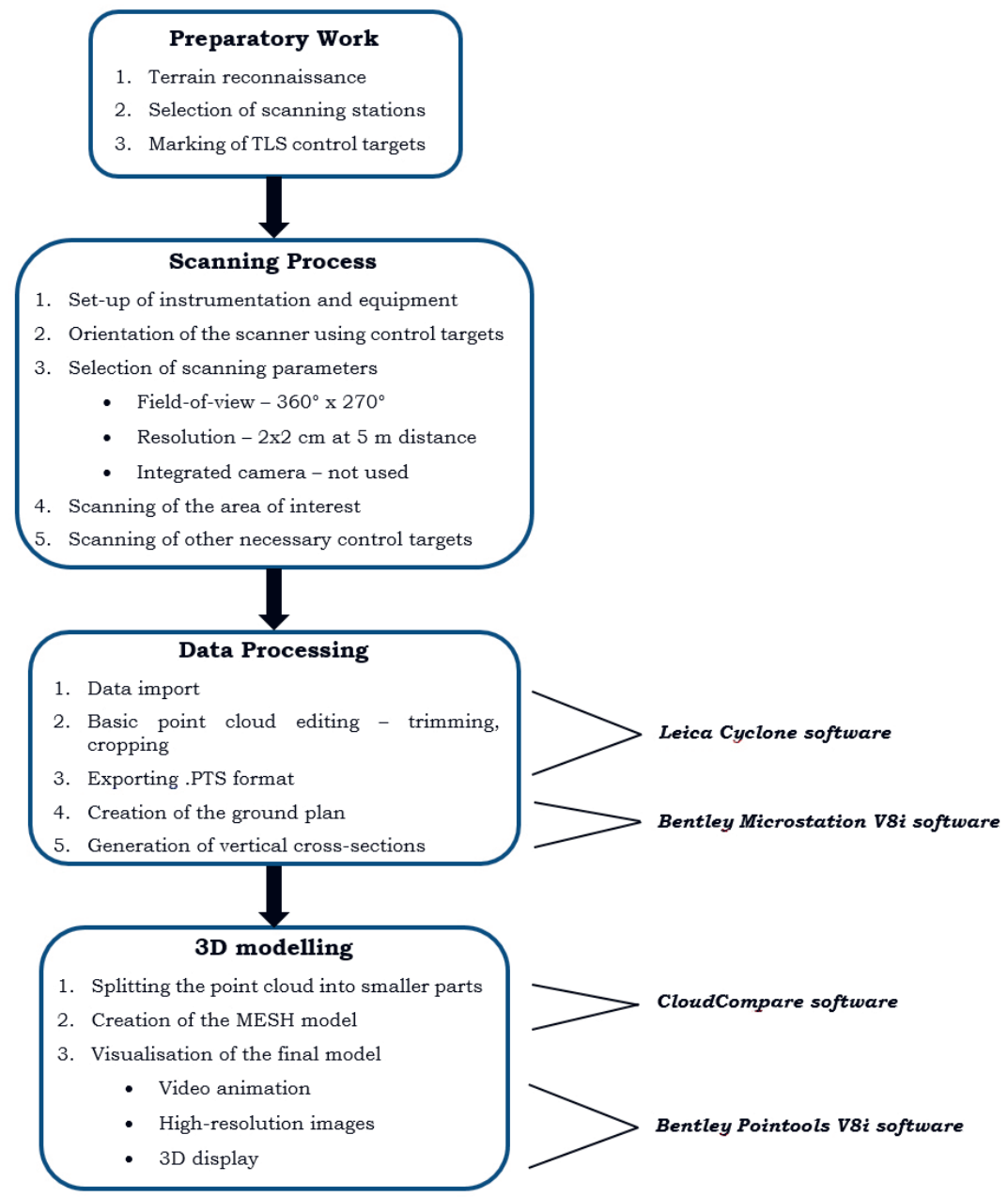

Fig. 12. General workflow diagram 


\subsection{Use of a 3D Model of the Bear Cave for Geotourism Development}

Since the Bear Cave is located $27 \mathrm{~km}$ away from a former Roma settlement in Letanovský Mlyn and the settlement does not currently serve any purposes, we propose using the location for the creation of an educational theme park. The proposal of a theme park (Fig. 13) could be considered as a certain type of a modern prehistoric museum, with its indoor and outdoor exhibits, which could serve for an educational purpose with the use of various amusing elements and recreational facilities. Visualization of the theme park was created by using a 3D modelling program SketchUp, in the same way, a video visualization was also created.

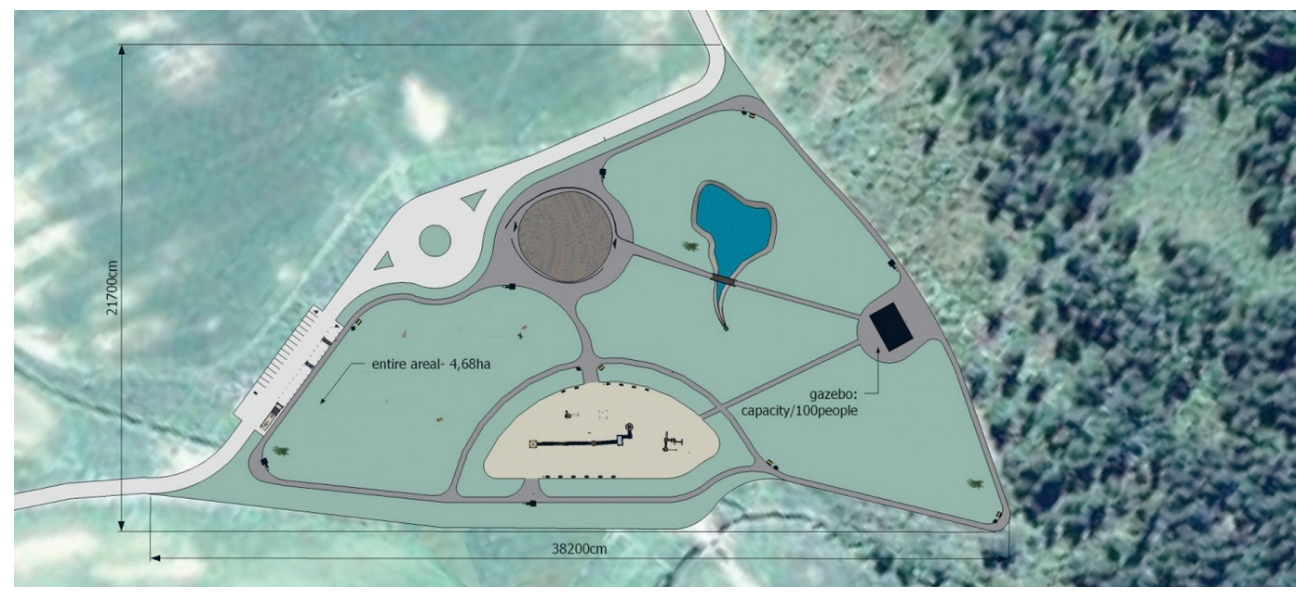

Fig. 13. Proposal of the theme park complex in Letanovský Mlyn

In order to make the theme park attractive for tourists and geotourists, a proposal was drafted to create a $3 \mathrm{D}$ projection hall (Fig. 14). The dimensions of the proposed single-storey hall are $38.80 \mathrm{~m} \times 37.80 \mathrm{~m}$. The proposed building is $9.5 \mathrm{~m}$ high. A part of the hall would be a 3D cinema (Fig. 15) included 3D simulation rides which is the combination of stereoscopic cinema and the active participation of visitors (moving seats), the movements are adjusted to the type of projected movie. The seating capacity of the proposed cinema is 55 seats.

In the projection hall, visitors could watch 3D documentary movies connected to the area of Lower Spiš with the 3D projection of the Bear Cave, an exhibition of prehistoric animals or mining exposition. The projection hall would also contain reception, gift shop, conference and lecture rooms.

The selected area has about 4.68 ha (the longest length is $382 \mathrm{~m}$, and the largest width is $217 \mathrm{~m}$ ). The theme park would be adapted to the average daily attendance of 1,000 people. The advantage of the theme park would be its location, as it 
is situated near National Park Slovak Paradise, which has a seasonal summer attendance of about 310,000 tourists. Construction of the park is proposed just $3 \mathrm{~km}$ from a thermal borehole in Arnutovce and $1 \mathrm{~km}$ far from the drill in Letanovce. The presence of the thermal springs opens the opportunity for building up a thermal pool as a part of the theme park.

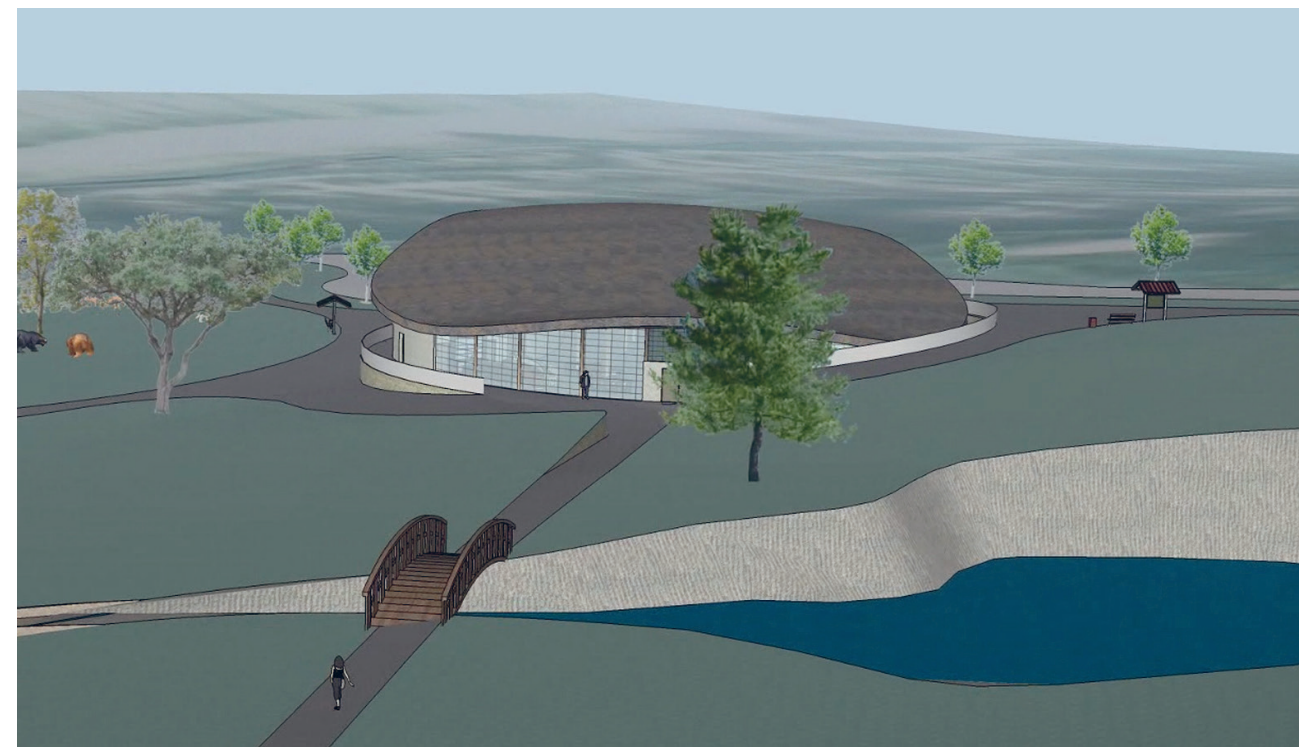

Fig. 14. Proposal for 3D projection hall

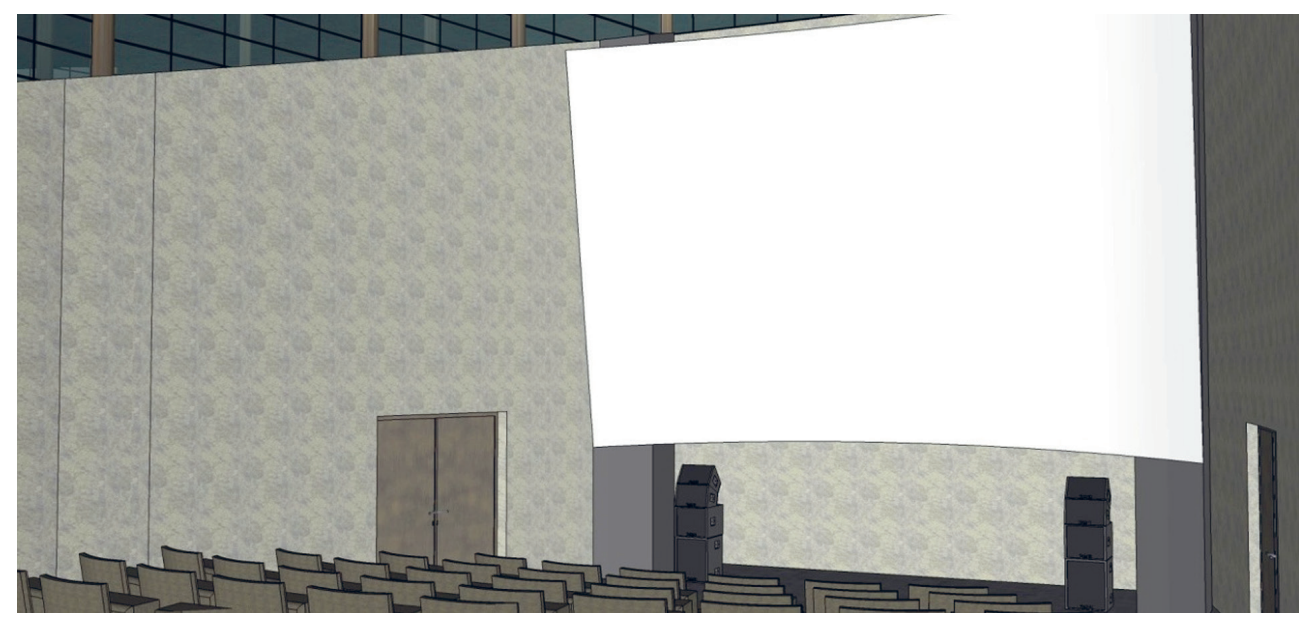

Fig. 15. Proposal for 3D cinema 
Additional parts of the theme park like a playground, parking, information boards, gazebo and the exhibition of life-sized statues of prehistoric animals are supposed to be in the area as well. The prehistoric animal exhibition would be primarily made up of cave bears, but also bear dogs, and false sabre-toothed cats (Nimravidae, Sansanosmilus, Homotherium, Megantereon).

The proposed educational and amusement park is intended to draw out-of-town travelers and to enhance the status of the Lower Spiš area as a geotourist location.

Many different techniques, different software and many types of modelling tools exist for 3D modelling. Modelling tools make creating 3D models easier and more simple. Modelling tools help create virtual objects and environments for CAD, visualization, education, training and entertainment. AutoCAD and MicroStation are popular for 2D/3D mechanical designing and drawing. All modelling tools provide certain drawing capabilities to visualize the models generated [19].

It is worth pointing out that laser scanning has some downsides such as price, the need of significant amount of time and effort, the difficulty of working in tight areas, very close range, or during adverse atmospheric conditions. Additionally, in the case of low-light underground spaces (or even without any illumination), the integrated RGB camera cannot be used to photo-texture the point cloud with RGB data. However, the possibility of the use of laser scanning even in total darkness, due to the nature of its measurement by a laser beam, can be seen as a great advantage.

On the other hand, there are various geotourism fields where 3D modelling could be used such as: natural heritage preservation, geo-surveying, cinematography, mining and caving. By using this sustainable technology, development can be achieved together with the conservation of geoheritage. Since accessibility, subsequent illumination and visiting caves by tourists often causes disruption of cave formations, micro-flora and fauna and each cave have a specific flux (visitors for time unit) tolerance limit, creating a 3D model could be a solution how to keep fragile cave environment sustainable. In addition to the 3D model, a visitor center or an educational theme park needs to be set up in the Slovak Paradise National Park or its surrounding area. The proposal of the educational theme park was already an object of the paper compiled by Tometzová, Hlavňová \& Rybár [39]. In the 3D cinema hall of the educational theme park, 3D models of the cave as an animation would be presented. The Bear Cave 3D model could be improved by creating a 3D model of cave bears, their bones or models of other extinct animals that lived in the area of Slovak Paradise in the past (like sabre-toothed cats). This would extend the target group to families with children and elementary schools.

Additionally, from the 3D models and animations of the cave, a virtual tour for devices displaying VR (3D glasses) or AR, which would be one of the attractions of the proposed theme park, could be designed. In Slovakia, most of the visitor centers, tourist centers and museums are still technically obsolete, consisting only of static expositions, and just a few Slovak tourist sites currently use visual, 
interactive elements and tools of virtual or augmented reality. Modern technology tools can provide visitors (especially families with children) with a much more intense experience and awaken their interest in Earth science and geoscience.

\section{Conclusion}

Currently, the most realistic option to provide information to tourists and give them an opportunity to access the interior of inaccessible caves is their visualization. Creating digital models and views of the spatial structure of geosystems, or other natural and technogenic phenomena in caves, is allowed by geographical information systems with georeferenced data.

Near the Bear cave, a 3D projection would draw the attention of visitors as they enter the bowels of the cave, at least through the screen. By using 3D technology, visitors could get information about the genesis of the cave, geomorphological settings, the prehistoric fauna that occurred here in the past, about the reasons for the extinction of cave bears, but also about the flora and animals living in the cave today or finds that archaeologists made here. It could be the solution of how to develop cave tourism without harmful consequences on this fragile environment.

Results of scanning can be useful not only for the general public but also for cavers, archaeologists, students and educational institutions. Digital recording could be the heritage for future generations, and 3D model much more accurately shows the morphology of underground spaces, including the fault zones or lines. It allows the orientation of fractures to be identified, even in hard-to-reach areas like high ceilings and walls. 3D modelling can also be used in presenting or attracting other underground sights in Slovakia without negative effects on its environment, for example, like in the case of Bear Cave in Poland [40, 41].

\section{References}

[1] Hose T.: The English Origins of Geotourism (as a Vehicle for Geoconservation) and Their Relevance to Current Studies. Acta Geographica Slovenica, vol. 51(2), 2011, pp. 343-359. https://doi.org/10.3986/ags51302.

[2] Wimbledon W.A.P.: Geosites - A New Conservation Initiative. Episodes, vol. 19(3), 1996, pp. 87-88.

[3] Dernas M., Maekawa S., Bell J., Agnew N.: Sustainable visitation at the Mogao Grottoes: A Methodology for Visitor Carrying Capacity. [in:] Agnew N. (ed.), Conservation of Ancient Sites on the Silk Road: Proceedings of the Second International Conference on the Conservation of Grotto Sites, Mogao Grottoes, Dunhuang, People's Republic of China, June 28-July 3, 2004, Getty Publications, 2010, pp. 160-169. 
[4] Jurinčič I., Balažič G.: Determining the carrying capacity of the Škocjan caves park for the implementation of sustainable visitor management. [in:] Jere Jakulin T. (ed.), Turizem in kakovost življenja: mednarodna konferenca: zbornik povzetkov [Tourism and quality of life: international conference: book of abstracts], Turistica, Fakulteta za turistične študije, Portorož 2011, pp. 205-215.

[5] Lobo H., Moretti E.: Tourism in Caves and the Conservation of the Speleological Heritage: The Case of Serra da Bodoquena (Mato Grosso do Sul State, Brazil). Acta Carsologica, vol. 38(2-3), 2009, pp. 265-276. https://doi.org/10.3986/ ac.v38i2-3.127.

[6] Lobo H., Trajano E., Marinho M., Bichuette M., Scaleante J., Scaleante O. et al.: Projection of tourist scenarios onto fragility maps: Framework for determination of provisional tourist carrying capacity in a Brazilian show cave. Tourism Management, vol. 35, 2013, pp. 234-243. https://doi.org/10.1016/j.tourman. 2012.07.008.

[7] Furey N., Racey P.: Conservation Ecology of Cave Bats. [in:] Voigt C., Kingtson T. (eds.), Bats in the Anthropocene: Conservation of Bats in a Changing World, Springer International Publishing, 2016, pp. 463-500.

[8] Cardiff S., Ratrimomanarivo F., Rembert G., Goodman S.: Hunting, disturbance and roost persistence of bats in caves at Ankarana, northern Madagascar. African Journal of Ecology, vol. 47(4), 2009, pp. 640-649. https://doi. org/10.1111/j.1365-2028.2008.01015.x.

[9] Cosso T., Ferrando I., Orlando A.: High-precision laser scanning for cave tourism: 3D reconstruction of the Pollera cave, Italy. GIM International, vol. 29(3), 2015, pp. 23-26.

[10] Buchroithner M., Gaisecker T.: Terrestrial Laser Scanning for the Visualization of a Complex Dome in an Extreme Alpine Cave System. Photogrammetrie Fernerkundung - Geoinformation, Heft 4, 2009, pp. 329-339. https://doi. org/10.1127/1432-8364/2009/0025.

[11] Custódio R., Dantas M., Prata A., Donato C., Morato L.: O turismo virtual de cavernas como instrumento didático-inclusivo. Nature and Conservation, vol. 6(2), 2014, pp. 71-84. https://doi.org/10.6008/ess2318-2881.2013.002.0008.

[12] Cui J., Chow Y., Zhang M.: A voxel-based octree construction approach for procedural cave generation. International Journal of Computer Science and Network Security, vol. 11(6), 2011, pp. 160-168.

[13] Ballesteros D., Jiménez-Sánchez M., Domínguez-Cuesta M.: Geomorphological maps and 3d models in cave research. [in:] European Geoscience Union General Assembly 2013, European Geoscience Union Vienna 2013, pp. 7-12.

[14] Remondino F.: Heritage Recording and 3D Modeling with Photogrammetry and 3D Scanning. Remote Sensing, vol. 3(6), 2011, pp. 1104-1138. https://doi. org/10.3390/rs3061104. 
[15] Leonov A., Anikushkin M., Bobkov A., Rys I., Kozlikin M., Shunkov M. et al.: Development of a Virtual 3d Model of Denisova Cave in the Altai Mountains. Archaeology, Ethnology and Anthropology of Eurasia, vol. 42(3), 2014, pp. 14-20. https://doi.org/10.1016/j.aeae.2015.04.003.

[16] Núñez M., Buill F., Edo M.: 3D model of the Can Sadurní cave. Journal of Archaeological Science, vol. 40(12), 2013, pp.4420-4428. https://doi.org/10.1016/ j.jas.2013.07.006.

[17] Gallay M., Kaňuk J., Hochmuth Z., Meneely J., Hofierka J., Sedlák V.: Large-scale and high-resolution 3-D cave mapping by terrestrial laser scanning: a case study of the Domica Cave, Slovakia. International Journal of Speleology, vol. 44(3), 2015, pp. 277-291. https://doi.org/10.5038/1827-806x.44.3.6.

[18] Bieda A., Bydłosz J., Parzych P., Pukanská K., Wójciak E.: 3D Technologies as the Future of Spatial Planning: the Example of Krakow. Geomatics and Environmental Engineering, vol. 14(1), 2020, pp. 15-33. https://doi.org/10.7494/ geom.2020.14.1.15.

[19] Chen J.: Data Visualization and Virtual Reality. [in:] Rao C.R., Wegman E.J., Solka J.L. (eds.), Data Mining and Data Visualization, Handbook of Statistics, vol. 24, Elsevier, 2005, pp. 539-563. https://doi.org/10.1016/s01697161(04)24017-2.

[20] Mack G.: Nouvelles présentations au Queensland Museum, Brisbane. Museum International (Edition Francaise), vol. 6(3), 2009, pp. 178-183. https://doi. org/10.1111/j.1755-5825.1953.tb00141.x.

[21] Feruglio V., Péral J., Aujoulat N.: Déclinaison d'une base de données 3D - Sur les pas de Breuil, une visite virtuelle de Lascaux. In Situ, vol. 13, 2010. https://doi. org/10.4000/insitu.6783.

[22] Carmo M., Cláudio A.: 3D Virtual Exhibitions. DESIDOC Journal of Library \& Information Technology, vol. 33(3), 2013, pp. 222-235. https://doi. org/10.14429/djlit.33.3.4608.

[23] Rezníček J., Pavelka K.: New low-cost 3D scanning techniques for cultural heritage documentation. The International Archives of the Photogrammetry, Remote Sensing and Spatial Information Sciences, vol. 37, 2008, pp. 237-240.

[24] Štroner M., Pospíšil J., Kostka B., Křemen T., Urban R., Smítka V., Třasák P.: 3D skenovací systémy. České vysoké učení technické v Praze, Praha 2013.

[25] Štroner M., Michal O., Urban R.: Maximal precision increment method utilization for underground geodetic height network optimization. Acta Montanistica Slovaca, vol. 22(1), 2017, pp. 32-42.

[26] Slovak Caves Administration. www.ssj.sk [access: 1.10.2019].

[27] Tulis J.: Anthropogenic impact on Karst regions in the National Park "Slovak Paradise". Studia Carsologica, vol. 3, 1990, pp. 45-55.

[28] Benický V.: Medvedia jaskyňa. Slovenský Kras, 1, 1958, pp. 116-117. 
[29] Blaha L.: O Medvedej jaskyni. Krásy Slovenska - Príloha 7, 30(10), 1953.

[30] Národná prírodná pamiatka Medvedia jaskyňa. 2019. http://uzemia.enviroportal. sk/main/detail/cislo/610 [access: 1.10.2019].

[31] Tulis J.: Medvedia jaskyňa v Slovenskom raji. [in:] Výskum, využívanie a ochrana jaskýň, 4. vedecká konferencia s medzinárodnou účast’ou, Tále, Slovakia 2003, pp. 55-72.

[32] Sásik C.: Geologicko-paleontologický výskum Medvedej jaskyne v Slovenskom raji. Krásy Slovenska - Príloha 7, 30(10), 1953.

[33] Novotný L., Tulis J.: Kras slovenského raja. Správa slovenských jaskýň, Liptovský Mikuláš 2005.

[34] Fejfar O.: Zpráva o výzkumu Medvědí jeskyně ve Slovenském raji. Krásy Slovenska - Príloha 7, 30(10), 1953.

[35] Bella P.: Geomorfologické faktory priestorovej diferenciácie, časových a časopriestorových zmien jaskynných geosystémov. Geomorphologia Slovaca et Bohemica, vol. 11(2), 2011, pp. 19-31

[36] Bendík A.: Medved’ jaskynný - mýtus a skutočnost' [Blog]. 21.04.2011. https:// bendik.blog.sme.sk/c/263103/Medved-jaskynny-mytus-a-skutocnost-I-cast. html\#ixzz2m8FWkHle [access: 1.10.2019].

[37] Bella P.: Genetické typy jaskýň. Verbum, Ružomberok 2011.

[38] Bolitho M., Kazhdan M., Burns R., Hoppe H.: Multilevel streaming for out-of-core surface reconstruction. [in:] Proceedings of the Fifth Eurographics Symposium on Geometry Processing, Barcelona, Spain, July 4-6, 2007, ACM International Conference Proceeding Series, 257, Eurographics Association, 2007, pp. 69-78.

[39] Tometzová D., Hlavňová B., Rybár P.: The proposal on educational theme park for local tourism development. Research Journal of Mining, vol. 1(3), 2017, pp. 139-145.

[40] Jaskinia Niedźwiedzia w Kletnie [Bear Cave in Kletno]. http://jaskinianiedzwiedzia.pl [access: 1.10.2019].

[41] Cacoń S., Mąkolski K., Kaczałek M.: Land-surveying measurements realized in Jaskina Niedźwiedzia by employees and students of Wroclaw University of Environmental and Life Sciences. [in:] Materiaty 48. Sympozjum Speleologicznego: Kletno, 16-19.10.2014 r., Sekcja Speleologiczna Polskiego Towarzystwa Przyrodników im. Kopernika, Kraków 2014, pp. 61-62. 


\section{Rozwój geoturystyki \\ z wykorzystaniem cyfrowego modelu 3D na przykładzie Jaskini Niedźwiedziej na Słowacji}

Streszczenie: Turystyka jaskiniowa (speleoturystyka) to bardzo popularna na całym świecie forma geoturystyki. Realizowana jest ona także na Słowacji, która jest znana ze swoich krasowych obszarów i jaskiń. Niestety większość z tych jaskiń nie jest swobodnie dostępna dla zwiedzających. Niniejszy artykuł przedstawia, jak „udostępnić" jaskinię bez konieczności fizycznego wchodzenia do niej. Jest to możliwe dzięki wykorzystaniu cyfrowych modeli 3D. Zwiedzający będą mogli doświadczyć zwiedzania jaskini za pośrednictwem projekcji 3D i kina 3D. Pozwoliłoby to niepełnosprawnym oraz osobom z klaustrofobią cieszyć się wizytą w jaskini. Dodatkową zaletą takiej formy zwiedzania jest to, że środowisko jaskiniowe pozostaje nietknięte. Autorzy opisują pomiar Jaskini Niedźwiedziej przy użyciu naziemnego skanera laserowego Leica ScanStation C10. Podczas jej trójwymiarowego modelowania, do przetwarzania i analizy dużych zbiorów danych zarejestrowanych przez skaner, wykorzystano oprogramowanie Trimble RealWorks. W wyniku skanowania laserowego uzyskano nie tylko wizualizacje i obrazy modeli 3D z jaskini, ale także animacje 3D wykonane przy użyciu oprogramowania Bentley Pointools. Informacje zawarte w niniejszym opracowaniu zostały zebrane ze wszystkich faz pomiarów Jaskini Niedźwiedziej i przetwarzania danych.

\section{Słowa}

kluczowe: geoturystyka, cyfrowy model 3D, naziemny skaning laserowy, Słowacki Raj, Jaskinia Niedźwiedzia 